\title{
Late Cretaceous Sedimentary Evolution Characteristics in Songliao Basin, Northeastern China
}

\author{
Chao Wang \\ Daqing Oilfield Exploration and Development Research Institute, China
}

57113728@qq.com

Keywords: Late Cretaceous; Base level Sedimentary evolution; Songliao Basin; Slump Fan.

\begin{abstract}
Late Cretaceous Yaojia-Nengjiang Formation in Songliao Basin is a set of sedimentary formation with the integrated base level rising and falling. The oil shale, formed during the maximum flooding surface period at the bottom of $\mathrm{K}_{2} \mathrm{n}_{2}$, distributed steadily in the whole basin. The oil shale was not only the standard interface for sequence and stratigraphic correlation, but also an important source rock and cap rock. $\mathrm{K}_{2} \mathrm{y}$ and $\mathrm{K}_{2} \mathrm{n}_{1}$ are large-scale lacustrine and retrograded delta sediment formed in lacustrine transgression period. Sediments of $K_{2} n_{2}$ and $K_{2} n_{5}$ were large-scale lacustrine and procreation delta sediment formed in forced lacustrine regression period. Gravity flow channel and terminal turbidity fan were developed in the major axis direction of the material source during the lacustrine transgression period of $K_{2} n_{1}$. Large-scale slump fan sediment was developed in front of the procreation delta during the forced lacustrine transgression period of $K_{2} n_{2}$.
\end{abstract}

\section{Introduction}

Over the past 50 years, Songliao Basin have accumulated abundant data and contributed to the new achievements in the basic geologic study of sedimentary geology, including gravity flow channel, slump fan, sublacustrine fan and various delta sediments. Especially the discovery of forced regressive sequence provides basis for reconstructing sedimentary filling and evolution history, established a relationship between sequence type and sedimentary filling pattern, and explores the control effect of sedimentary filling pattern on hydrocarbon accumulation and distribution.

\section{Geological background of Songliao Basin}

The sedimentary cap rock of Songliao Basin formed in cretaceous and was overlain with a small amount of Cenozoic formation. The basement is of Paleozoic and pre-Paleozoic metamorphic, magmatic and volcanic rocks ( $\mathrm{Li}, 1996$; Jia, 2007). The tectonic evolution of Songliao Basin is divided into three periods, including fault, depression and inversion (Yang, 1985; Wang, 1993; Hu, 1998).

The formations formed during faulting period are composed of volcanic rocks, sandy conglomerates, gritstone formed in fan delta, and mudstone intercalated with coal bed formed in faulted lake basin mainly. The formation formed in inversion period was composed of interbeded sandstone and mudstone formed in river, shallow lake and delta, with mainly shallow biogas (Zhang, 2004) The formation formed during depression period contained interbeded and overlapped lithologic combination of sandstone in large-scale river, delta, and large-scale mudstone and oil shale in large-scale lake.

\section{Late Cretaceous Sedimentary evolution of K2y and K2n}

Late Cretaceous of $\mathrm{K}_{2} \mathrm{y}$ and $\mathrm{K}_{2} \mathrm{n}_{1}$ is a large-scale lacustrine and regressive delta deposit formed during lacustrine progradation. $\mathrm{K}_{2} \mathrm{y}$ has multi-source, multi-sedimentary system and a half-ring facies belt (Gao, 1980). The formation is thicker in the middle and thinner on the edge.

From the edge of the basin to the central, the combination of sedimentary facies belt is river, delta, shore, shallow lacustrine and semi deep lake. The lake region only counts for one third of the total 
area. The large-scale deltaic complex developed in the northern water system, which is the largest sedimentary in Songliao basin.

The sedimentary facies belts of $\mathrm{K}_{2} \mathrm{y}_{2}$ and $\mathrm{K}_{2} \mathrm{y}_{3}$ are similar to the zonal distribution of $\mathrm{K}_{2} \mathrm{y}_{2}$. But the sedimentary facies belts are narrower than delta facies belt. The area of lacustrine region expanded twice and deep lake region appeared. Generally, the material source of upper- $\mathrm{K}_{2} \mathrm{y}$ mainly came from the northern water system. Although there were many material sources from the west, the amount was not large.

In the eastern part of the system, the two small material sources developed in Nong'an and Shuangcheng had relatively narrow facies belt and therefore had less influence on the general sedimentary environment. During the depositing period of $\mathrm{K}_{2} \mathrm{n}_{1}$, lake expanded rapidly and water nearly covered the whole basin. Semi-deep lake and deep lake sediment were widely distributed in the central part of basin. The most significant sedimentary characteristics is a large-scale gravity flow channel developed from delta front to the deep lake area in the northern water system (Feng, 2006, 2010).

The channels generally extended in the south direction, and formed a sublacustrine fan at the end of the channel in deep-lake region. $K_{2} n_{2}$ to $K_{2} n_{5}$ in Songliao Basin is a large-scale lacustrine and progradation delta deposit formed during forced water regression. Songliao Basin's deposition region was the greatest at the bottom of $K_{2} n_{2}$ Today, most parts of the basin are within semi-deep or lake-deep lake area.

This is the second large-scale lake invasion occurred after Member 1 of Qingshankou Formation $\left(\mathrm{K}_{1} \mathrm{qn}_{1}\right)$ in Songliao Basin, high quality oil shale formed and distributed in the whole basin . After the $K_{2} n_{2}$ invasion event, the eastern part of the basin began to rise, and the direction of material source changed greatly.

Sources from the south, west and north disappeared and material from the east became the only source. With the eastern part of basin rising rapidly, sediments rapidly advanced to the lake area and formed a high-angle progradation delta.

Besides, several slump fans formed in the delta front due to gravity, which is similar to the turbidity fan formed during descending period of Qingshankou Formation's base level. In $K_{2} n_{3}$, there is a large-scale denudation region in the eastern part of basin. A lacustrine-delta sedimentary environment formed in the basin.

Today, in $\mathrm{K}_{2} \mathrm{n}_{4}$ and $\mathrm{K}_{2} \mathrm{n}_{5}$ of Songliao Basin, the original lake almost disappeared, except some shallow shore lakes sparsely distributed in the southern part and the northern part of the original lake. The sedimentary facies are shallow shore lacustrine delta and river. A large denudation area exists around the basin (Figure 1).

\section{Oil-bearing combination characteristics}

Oil-bearing combination controlled by water progressive sequence. During depression period of Songliao Basin, $\mathrm{K}_{2} \mathrm{qn}_{1}$ and $\mathrm{K}_{2} \mathrm{n}_{1-2,} 2$ sets of lake flooding mudstone and oil shale, developed with high organic abundance, great thickness, and wide distribution. Sapropel organic matter is the main material of the mudstone.

Organic carbon content is in the whole sequence in central depression unit. Most of the sequence is in mature stage. The sequencehad good oil generation capacity and was the main hydrocarbon source of Songliao Basin. Putaohua and Saertu Oil layers are retrogradation stratigraphic sequence formed in transgression, and had lacustrine mudstone deposited in the upper part as cap rock during lake flooding period of $\mathrm{K}_{2} \mathrm{n}_{1-2}$. $\mathrm{K}_{2} \mathrm{qn}_{1}$ deposited in the lower part as source rock. formed an oil-bearing combination of lower generation and upper storage.

Oil-bearing combination controlled by forced water regressive sequence. Heidimiao Oil-layer is a procreation sequence deposited in forced regression environment. Lower $\mathrm{K}_{2} \mathrm{n}_{1-2}$ semi-deep lacustrine and deep lacustrine mudstone. Organic matter maturity $\left(R_{O}\right)$ is generally greater in central depression unit in Qijia-Gulong Sag at deeper buried depth where the main source rock of Heidimiao Oil-layer locates. 
Oil source analysis also showed that some oil was from the source rock of $\mathrm{K}_{2} \mathrm{qn}_{1}$. Thus, oil in Heidimiao Oil-layer has mixed sources. Because Heidimiao Oil-layer is a forced progradation sequence, its upper part is lack of regional continuously distributed flooding mudstone cap rock in the whole basin.

But it has lacustrine mudstones intercalated between rapid progradation deltas as cap rock. Therefore, Heidimiao Oil-layer has an oil bearing combination similar to Putaohua and Saertu Oil-layers. The reservoir distribution of Heidimiao oil layer was controlled by the distributions of mature source rock and regional cap rocks.

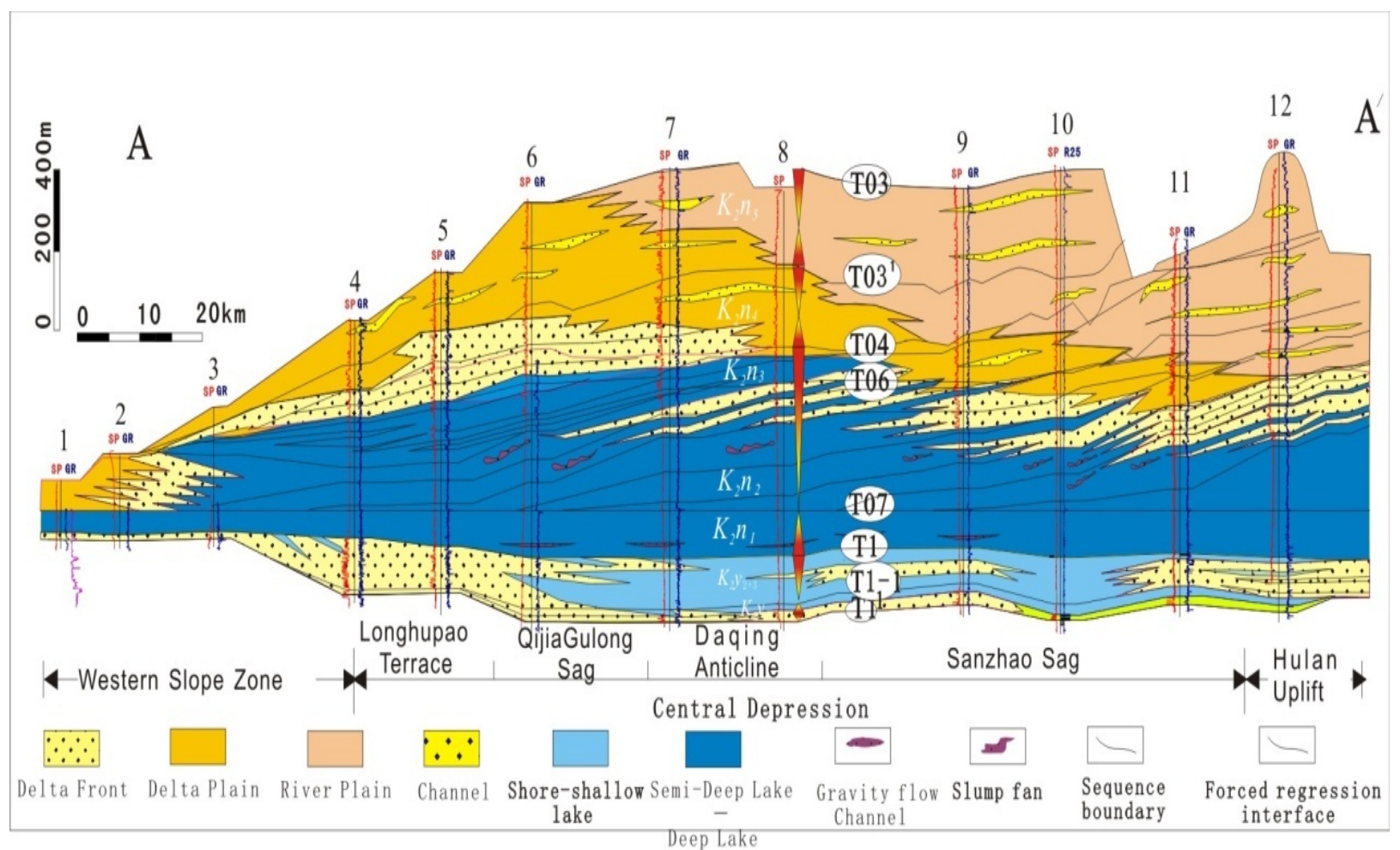

Fig.1 East-west sedimentary profile map from $\mathrm{K}_{2} \mathrm{y}$ to $\mathrm{K}_{2} \mathrm{n}$ of Songliao Basin

\section{Conclusions}

$\mathrm{K}_{2} \mathrm{y}-\mathrm{K}_{2} \mathrm{n}$ of Songliao Basin is a set of formation with integrated rise and fall cycle of base level. The rise and fall of the base level caused large fluctuation on Lake Leveland therefore controlled sequence types, sedimentary filling and evolution. The rising cycle on base level controlled the transgression sequence of $\mathrm{K}_{2} \mathrm{y}$ and $\mathrm{K}_{2} \mathrm{n}_{1}$ and correspondingly formed a low angle retrogradation delta and a large-scale gravity flow channel deposit. The falling cycle on base level controlled the forced regression sequence of $\mathrm{K}_{2} \mathrm{n}_{2-5}$ and correspondingly formed a high angle progradation delta and a large-scale gravity slump fan deposit.

The large-scale delta complex developed along the major axis was a good reservoir for hydrocarbon accumulation and controlled the distribution of large-scale structural reservoir. The delta front facies belts developed along the minor axis are mainly braided channel, mouth bar, and sheet sandbody and consequently controlled the distribution of lithological reservoir.

\section{References}

[1] Li Desheng. 1996,Basic characteristics of oil and gas basins in China [J]. Journal of Sourheart Asian Earth Sciences, Vol. 13, p299-304. (In Chinese)

[2] JIA Chengzao.2007, The Characteristics of Intra-continental Deformation and Hydrocarbon Distribution Controlled by the Himalayan Tectonic Movements in China. Earth Science Frontiers, Vol. 14, No.4, p 96-104. 
[3] Yang Wanli. 1985,Hydrocarbon Geological Characteristics in Continental Songliao Basin [M].Beijing: Petroleum Industry Press. (In Chinese)

[4] Wang Dongpo.1993,Sedimentary Construction and Sea Level Rise-fall in Songliao Basin [M]. Beijing: Geological Press. (In Chinese)

[5] Wangshui Hu, Chunfang Cai, Zhiyong Wu, et al.. 1998,Structural style and its relation to hydrocarbon exploration in the Songliao basin, northeast China, Marine and Petroleum Geology ,v15,p41-55.

[6] Zhang Shun, Feng Zhiqiang, Lin Chunming, etc. 2004,Cenozoic Biogas Gathering and Accumulation Conditions in Songliao Basin [J].Acta Petrolei Sinica, 25(3):18-22. (In Chinese)

[7] Gao Ruiqi. 1980, Cretaceous Continental Sedimentary Characteristics in Songliao Basin [J].ACTA GEOLOGICA SINICA,1: 9-26. (In Chinese) 